\title{
FAKTOR-FAKTOR YANG MEMPENGARUHI MINAT PEMILIHAN KARIR SEBAGAI AKUNTAN PUBLIK DAN NON AKUNTAN PUBLIK (Studi Kasus pada Mahasiswa Progran Studi S1 Jurusan Akuntansi Universitas Mercu Buana Yogyakarta)
}

\author{
Eviy Rosmalinda dan Diana Airawaty \\ Universitas Mercu Buana Yogyakarta \\ Email: eviyrosmalinda@gmail.com, d_airawaty@gmail.com
}

\begin{abstract}
The purpose of this study is to investigate and analyse the factor that will influence the selection of accounting student in a public accounting career and non a public accounting career. Factor that's influence the career choice become public accounting variabels financial rewards, professional training, social value, work environment, labor market considerations and personality. The primary data in this study were obtained by performing the university Mercu Buana Yogyakarta Campus 2 accounting student discourse with a total sample of 69 students. Analysis tools used in this study in logistic regression. The resuld showed that simultaneous variable financial rewards, professional training, social value and personality significantly influence career choice public accountants. While work environment and labor market consideration not significan influence career choice public accountants.
\end{abstract}

Keywords: Financial reward; professional training; social value, work environment; labor market considerations

\section{A. PENDAhULUAN}

Semakin pesatnya pertumbuhan ekonomi tentunya membuat banyak angkatan kerja bersaing untuk mendapatkan pekerjaan, tidak terkecuali bagi lulusan mahasiswa ekonomi jurusan akuntansi baik pada perguruan tinggi negeri maupun swasta. Persaingan di dunia bisnis tentunya mendorong mereka untuk menjadi mahasiswa yang berkualitas dan siap memasuki dunia kerja. Untuk itu mereka harus dibekali kemampuan baik sejak dari bangku kuliah maupun di luar kuliah agar mereka mampu berkompetensi di dunia kerja (Enggar Nursasi dan Yuyuk Liana, 2009).

Mahasiswa fakultas ekonomi jurusan akuntansi mempunyai paling tidak tiga alternatif langkah yang dapat ditempuh dalam karir di bidangnya. Pertama, setelah menyelesaikan pendidikan ekonomi jurusan akuntansi seseorang dapat langsung kerja. Bidang pekerjaan yang tersedia untuk lulusan ini cukup bervariasi, antara lain sebagai wiraswasta dan bekerja pada instansi pemerintah atau perusahaan. Kedua, melanjutkan pendidikan akademik pada jenjang S-2. Ketiga, melanjutkan pendidikan profesi untuk menjadi akuntan publik (Aprilyan dan Laksito 2011). Dengan kata lain setelah menyelesaikan pendidikan jenjang program sarjana jurusan akuntansi, Setiap sarjana akuntansi bebas untuk memilih karir yang akan dijalaninya sesuai dengan keinginan dan harapannya masingmasing. Bagi yang memilih profesi 


\title{
PENGARUH LABA PER SAHAM, PENDAPATAN, DAN TOTAL ARUS KAS TERHADAP NILAI PERUSAHAAN (Studi Empiris pada Perusahaan Go Publik di Bursa Efek Indonesia Sektor Industri Barang Konsumsi dan Aneka Industri periode 2015-2016)
}

\author{
Akhmad Firdan Rakhman dan Nur ainy \\ Universitas Mercu Buana Yogyakarta \\ Email : firdanak14@gmail.com, akuntansi@mercubuana-yogya.ac.id
}

\begin{abstract}
Money managers clearly have a fiduciary duty to investigate before they invest client funds. The purpose of this per stock is, Income and Total cash flow the value of change both simultaneously and partial. This study employes a method of casual testing or case. Financial base was taken from a financial report of entities affiliated with the industrial facilities of the industrial food and a wide variety of industry in 2015-2016. The analysis data used a double regression analysis the result of a partial research directed that the income and total cash flow have an effect on the vale of the company. But the profit per share has no influence on the value of the company. The result of the research simultaneously indicate that a simultaneously return of the profit per share, the total cash flow and income has an effect the value of the company
\end{abstract}

Keywords: Earnings per Sahre, Revenue, Total cash flow, the value of the company

\section{A. PENDAhULUAN}

Tujuan utama perusahaan pada dasarnya mengacu pada pengoptimalan nilai perusahaan, semakin tinggi nilai perusahaan maka kemakmuran pemegang saham akan semakin meningkat. Nilai perusahaan sangat penting karena mencerminkan kinerja perusahaan yang dapat mempengaruhi persepsi investor terhadap perusahaan. Nilai perusahaan juga dapat dipengaruhi oleh laba per saham dengan arah positif, dimana semakin besar laba bersih per saham yang diperoleh perusahaan yang diidentifikasikan dengan nilai return.

Return memungkinkan investor untuk membandingkan keuntungan aktual ataupun keuntungan yang diharapkan dan disediakan oleh berbagai investasi pada tingkat pengembalian yang diinginkan. Disisi lain, return pun memiliki peran yang amat signifikan dalam menentukan nilai dari suatu investasi. Return juga merupakan keuntungan yang dinikmati oleh investor atas tindakan investasi yang dilakukan. Dalam investasi saham, investor akan memilih saham perusahaan yang memberikan tingkat keuntungan tertinggi. Sehingga perusahaan memerlukan laba yang cukup supaya bisa dapat bertahan dan berkembang.

Nilai perusahaan dapat memberikan kemakmuran pemegang sah Menurut Sofyan (2004) tujuan laporan keuangan yaitu pengambilan keputusan investasi dan pembiayaan, menilai prospek arus kas dan lain sebagainya. Informasi yang terkandung dalam laporan keuangan banyak memberikan manfaat bagi pengguna apabila laporan tersebut dianalisis lebih lanjut sebelum dimanfaatkan sebagai alat bantu pembuatan keputusan. Dari laporan 
keuangan perusahaan dapat diperoleh informasi tentang kinerja, aliran kas perusahaan, dan informasi lain yang berkaitan dengan laporan keuangan.am maksimum apabila harga saham meningkat. Semakin tinggi harga saham sebuah perusahaan, maka semakin tinggi pula kemakmuran pemegang saham. (Sudarsono, 2002).

Berdasarkan uraian di atas maka penelitian ini penting untuk diteliti. Penelitian ini bertujuan untuk meneliti pengaruh laba per saham, total arus kas dan pendapatan sebagai variabel independen terhadap variabel dependennya yaitu nilai perusahaan. Dengan melakukan penelitian ini, maka akan dapat diketahui apakah hasil penelitian ini akan sama dengan penelitian-penelitian sebelumnya, meskipun terdapat perbedaan pada objek yang diteliti, periode yang digunakan, serta pengembangan metode penelitiannnya dan disesuaikan dengan perkembangan teknologi sekarang.

Dalam menghadapi era pasar dan pemenuhan kebutuhan konsumsi masyarakat indonesia yang semakin meningkat, maka perusahaan sektor aneka industri dan sektor industri barang konsumsi diharapkan dapat berkembang. Untuk mewujudkan harapan tersebut maka perusahaan harus bergerak secara efisien. Maka, penulis tertarik untuk melakukan penelitian lebih lanjut mengenai perdagangan di pasar modal Indonesia, khususnya pada perusahaan sektor aneka industri dan sektor industri barang konsumsi yang Go Public di Bursa Efek Indonesia, dengan judul Pengaruh Laba per Saham, Pendapatan, dan Total Arus Kas Terhaap Nilai Perusahaan (Studi Empiris pada Perusahaan Go Publik di Bursa Efek Indonesia Sektor Aneka Industri dan Sektor Industri Barang Konsumsi Periode 20152016)".

\section{B. TINJAUAN PUSTAKA}

Salah satu komponen informasi akuntansi yang terkandung dalam laporan keuangan mempunyai pengaruh terhadap nilai perusahaan antara lain perubahan dalam laba per saham, arus kas dan pendapatan. Ketiga komponen ini seringkali menjadi pertimbangan utama oleh para investor sebelum mengambil keputusan untuk menanamkan dananya di sebuah perusahaan. Neiderhaffer dan Regan membenarkan bahwa harga saham sangat bergantung pada perubahan pendapatan (Fabozzi, 1995).

Dengan memperhatikan laba per saham maka investor dapat mempertimbangkan untuk berinvestasi di pasar modal. Laba per saham dipengaruhi oleh pendapatan perusahaan. Jika pendapatan perusahaan tinggi maka laba per saham juga akan tinggi, begitu juga sebaliknya. Hal ini yang akan mempengaruhi harga saham, karena pergerakan harga saham pengaruh awalnya adalah pendapatan perusahaan (Suad Husnan, 2003).

Informasi tentang arus kas suatu perusahaan berguna bagi para pemakai laporan keuangan sebagai dasar untuk menilai kemampuan perusahaan dalam menghasilkan kas dan setara kas dan menilai kebutuhan perusahaan untuk menggunakan arus kas tersebut. Dalam proses pengambilan keputusan ekonomi, para pemakai perlu melakukan evaluasi terhadap kemampuan perusahaan dalam menghasilkan kas dan setara kas serta kepastian perolehannya. Tujuan Pernyataan ini adalah memberi informasi historis mengenai perubahan kas dan setara kas dari suatu perusahaan melalui laporan arus kas yang mengklasifikasikan arus kas berdasarkan aktivitas operasi, investasi maupun pendanaan (financing) selama suatu periode akuntansi.

Informasi yang terkandung dalam laporan keuangan banyak memberikan 
manfaat bagi pengguna apabila laporan tersebut dianalisis lebih lanjut sebelum dimanfaatkan sebagai alat bantu pembuatan keputusan. Dari laporan keuangan perusahaan dapat diperoleh informasi tentang kinerja (performance), aliran kas perusahaan, dan informasi lain yang berkaitan dengan laporan keuangan. Satu hal yang sangat penting untuk digarisbawahi adalah bahwa informasi yang diungkapkan dalam laporan keuangan menunjukkan seberapa besar nilai perusahaan (firm value).

\section{METODE PENELITIAN}

Pemilihan lokasi penelitian ini dilakukan di Bursa Efek Indonesia (BEI) melalui situs resminya yaitu www.idx.co.id, didasarkan atas pertimbangan objektif sesuai dengan tujuan penelitian. Dipilihnya BEI sebagai tempat penelitian karena BEI merupakan bursa pertama di Indonesia yang dianggap memiliki data yang lengkap dan telah terorganisasi dengan baik. Sedangkan objek dalam penelitian ini adalah laba per saham, pendapatan, total arus kas dan nilai perusahaan.

Penelitian ini bertujuan untuk melihat seberapa besar pengaruh laba per saham, total arus kas dan pendapatan terhadap nilai perusahaan. Peneliti melakukan pengamatan terhadap laporan keuangan auditan industri dari tahun 2015 sampai tahun 2016 yang tergabung di BEI pada perusahaan yang Go Publik di BEI sektor aneka industri dan industri barang konsumsi, dengan mengambil variabel berupa laba per saham, pendapatan dan total arus kas.

Total arus kas yang digunakan adalah kas dan setara kas akhir tahun. Pendapatan yang digunakan dalam penelitian ini adalah total pendapatan (total revenue) sebelum dikurangi dengan beban-beban. Dan nilai perusahaan yang digunakan dalam penelitian yaitu harga saham penutupan tahun dikalikan dengan jumlah lembar saham yang beredar ditambah nilai buku total hutang baru dibagi dengan nilai buku total aktivitas. Populasi yang menjadi objek penelitian ini adalah pada perusahaan yang Go Publik di BEI sektor industri barang konsumsi dan aneka industri dan menerbitkan laporan keuangan yang diaudit dan dipublikasikan di Bursa Efek Indonesia untuk periode tahun 20152016.

Teknik penarikan sampel yang digunakan adalah purposive sampling (sampel bertujuan). Menurut Nur Indriantoro (2002) purposive sampling yaitu tipe pemilihan sampel secara tidak acak berdasarkan penilaian tertentu mewakili statistik, tingkat signifikansi, dan atau prosedur pengujian hipotesis. Batasan dalam pengambilan sampel untuk penelitian ini adalah industriindustri yang tergabung dalam perusahaan pada perusahaanyang Go Publik di BEI sektor industri barang konsumsi dananeka industri periode 2015-2016.

Penelitian ini menggunakan metode pengujian hipotesis, khususnya pengujian hipotesis kausal atau sebab akibat, yaitu hipotesis yang menyatakan hubungan suatu variabel dapat menyebabkan perubahan variabel lainnya (Nur Indriantoro, 2002).

Dengan kata lain, metode ini menguji hipotesis atau menjawab pertanyaan yang menyangkut keadaan pada saat penelitian dilakukan. Informasi yang ingin diperoleh adalah informasi mengenai seberapa besar pengaruh suatu variabel atau seperangkat variabel terhadap variabel lainnya, baik pengaruh langsung, maupun tidak langsung.

Penelitian ini merupakan penelitian akademik yang dapat diaplikasikan dalam praktik bisnis maupun untuk perkembangan ilmu di kemudian hari. Karena itu berdasarkan tujuannya, penelitian ini merupakan penelitian dasar (fundamental research) karena tidak 
dibuat untuk memecahkan masalah yang ada saat ini.

Sofyan Syafri (2006) mendefinisikan penelitian dasar sebagai penelitian yang terutama dilakukan untuk meningkatkan pemahaman terhadap masalah tertentu yang kerap terjadi dan mencari metode untuk memecahkannya. Berdasarkan pendekatannya, penelitian ini merupakan penelitian kualitatif yang bersifat deskriptif dari hasil dua subpenelitian kuantitatif. Berdasarkan hubungan antar variabelnya, maka penelitian ini juga merupakan causal study.

\section{HASIL PENELITIAN}

Analisis regresi linier berganda digunakan untuk meneliti pengaruh laba per saham (X1), pendapatan(X2), dan total arus $\operatorname{kas}(\mathrm{X} 3)$ terhadap nilai perusahaan(Y). Model persamaan regresi linier berganda adalah sebagai berikut:

$\mathrm{Y}=\boldsymbol{\alpha}+\boldsymbol{\beta} 1 .(\mathrm{X} 1)-\boldsymbol{\beta 2} .(\mathrm{X} 2)+\boldsymbol{\beta 3} .(\mathrm{X} 3)+\mathbf{e}$

Tabel 1

Hasil Regresi Linier Berganda

\begin{tabular}{|c|c|c|c|c|c|c|}
\hline & \multirow{2}{*}{ Model } & \multicolumn{2}{|c|}{$\begin{array}{l}\text { Unstandardized } \\
\text { Coefficients }\end{array}$} & \multirow{2}{*}{$\begin{array}{c}\begin{array}{c}\text { Standardized } \\
\text { Coefficients }\end{array} \\
\text { Beta }\end{array}$} & \multirow{2}{*}{$\mathrm{T}$} & \multirow{2}{*}{ Sig. } \\
\hline & & B & $\begin{array}{l}\text { Std. } \\
\text { Error }\end{array}$ & & & \\
\hline \multirow{4}{*}{1} & (Constant) & $-4,290$ & 2,097 & & $-2,046$ &, 050 \\
\hline & Laba_Per_Saham &,- 163 &, 107 &,- 263 & $-1,517$ &, 140 \\
\hline & Pendapatan &, 043 & ,093 & ,097 & 2,466 &, 044 \\
\hline & Total_Arus_Kas &, 182 & ,088 & ,449 & 2,071 & ,047 \\
\hline
\end{tabular}

Sumber : Data diolah SPSS

Dari Tabel tersebut diperoleh hasil

sebagai berikut :

$\mathrm{Y}=-4,290-0,163$. EPS + 0,043.

Pendapatan $+0,182$.

Total Arus Kas + e

Keterangan :

Laba per Saham $=\left(\mathrm{X}_{1}\right)$

Pendapatan $\quad=\left(\mathrm{X}_{2}\right)$

Total Arus Kas $=\left(\mathrm{X}_{3}\right)$

Nilai Perusahaan $=(\mathrm{Y})$

$\alpha=$ (konstanta)

$\beta=($ Koefisien regresi $)$

$\mathrm{e}=$ (Eror)

\section{Uji Hipotesis}

a. Uji Parsial (Uji Statistik t)

1) Pengujian Hipotesis Pertama $\mathrm{H}_{1}$ : Laba per Saham Berpengaruh Positif terhadap Nilai Perusahaan.
Berdasarkan Tabel 1 diperoleh nilai Unstandardized BetaCoefficients dari earnings per share (EPS) sebesar -0,163 dengan signifikansi 0,140. Nilai signifikansi earnings per share yang lebih besar dari signifikansi yang diharapkan $(0,05)$ dan $\mathrm{t}$ hitung sebesar $-1,517<\mathrm{t}$ tabel sebesar 2,04523 menunjukkan bahwa variabel earnings per share berpengaruh negatif dan tidak signifikan terhadap nilai perusahaan aneka industri yang terdaftar di Bursa Efek Indonesia periode 2015-2016, sehingga hipotesis pertama yang diajukan ditolak.

2) Pengujian Hipotesis Kedua

$\mathrm{H}_{2}$ : Pendapatan Berpengaruh Positif terhadap Nilai Perusahaan. 
Berdasarkan Tabel 1 diperoleh nilai Unstandardized BetaCoefficients dari Pendapatan sebesar 0,043 dengansignifikansi $\quad 0,044 \quad$ Nilai signifikansi Pendapatan yang lebih kecil dari signifikansi yang diharapkan $(0,05)$ dan dan $t$ hitung sebesar $2,466>t$ tabel sebesar 2,04523 menunjukkan bahwa variabel Pendapatan berpengaruh positif dan signifikan terhadap nilai perusahaan sektor aneka industri yang terdaftar di Bursa Efek Indonesia periode 2015-2016, sehingga hipotesis kedua yang diajukan diterima.

3) Pengujian Hipotesis Ketiga

$\mathrm{H}_{3}$ : Total Arus Kas Berpengaruh Positif terhadap Nilai Perusahaan.

Berdasarkan Tabel 1 diperoleh nilai Unstandardized BetaCoefficients dari Total Arus Kas sebesar 0,182dengansignifikansi $\quad 0,047$ Nilai signifikansi Total Arus Kas yang lebih kecil dari signifikansi yang diharapkan $(0,05)$ dan $\mathrm{t}$ hitung sebesar 2,071> $t$ tabel sebesar 2,04523menunjukkan bahwa variabel Total Arus Kas berpengaruh positif dan signifikan terhadap nilai perusahaan sektor aneka industri yang terdaftar di Bursa Efek Indonesia periode 2015-2016, sehingga hipotesis ketiga yang diajukan diterima.

\section{b. Uji Simultan (Uji F)}

Pengujian ini bertujuan untuk mengetahui pengaruh laba per saham, pendapatan,dan total arus kasterhadap nilai perusahaan secara simultan. Uji $F$ digunakan unuk menguji kelayakan model dalam analisis linier regresi. Jika nilai signifikansi kurang dari 0,05 maka variabel independen dapat digunakan untuk memprediksi variabel dependen.

Tabel 2

Hasil Uji F

\begin{tabular}{|c|c|c|c|c|c|}
\hline Model & $\begin{array}{c}\text { Sum of } \\
\text { Squares }\end{array}$ & df & Mean Square & F & Sig. \\
\hline Regression & 5,829 & 3 & 1,943 & 2,999 &, $046^{\mathrm{b}}$ \\
$1 \quad$ Residual & 19,439 & 30 &, 648 & & \\
Total & 25,268 & 33 & & & \\
\hline
\end{tabular}

Sumber : Data diolah

$\mathrm{H}_{4}$ : Laba per saham, pendapatan, dan total arus kas secara stimultan berpengaruh terhadap nilai perusahaan.

Berdasarkan hasil pengujian pada Tabel 2, nilai signifikasi simultan bernilai 0,046 . Tingkat signifikansi tersebut lebih kecil dari 0,05 dan $\mathrm{F}$ hitung sebesar 2,999> F tabel sebesar 2,93403, yang artinya secara keseluruhan ketiga variabel berpengaruh terhadap nilai perusahaan, dapatdisimpulkan bahwa Laba per saham, pendapatan, dan total arus kas secara stimultan berpengaruh terhadap nilai perusahaan, sehingga $\mathrm{H}_{4}$ diterima.

\section{E. PEMBAHASAN}

1. Uji Parsial

a. Pengaruh Earnings Per Share terhadap Nilai Perusahaan

Earnings per share (EPS) sebesar 0,163 dengan signifikansi 0,140 . Nilai signifikansi earnings per share yang lebih besar dari signifikansi yang diharapkan $(0,05)$ dan $t$ hitung sebesar $1,517<\mathrm{t}$ tabel sebesar 2,04523 menunjukkan bahwa variabel earnings per 
share berpengaruh negatif dan tidak signifikan terhadap nilai perusahaan aneka industri yang terdaftar di Bursa Efek Indonesia periode 2015-2016, sehingga hipotesis pertama yang diajukan ditolak.

Penelitian ini tidak konsisten dengan penelitian yang telah dilakukan oleh Tito Perdana Putra, dkk (2007) yang menyatakan bahwa earnings per share berpengaruh positif dan signifikan terhadap nilai perusahaan. Hasil penelitian ini adalah salah satu temuan empiris yang berkaitan dengan ketidakteraturan (anomali) yang terdapat di pasar modal. Menurut Jones (1998), anomali pasar ini merupakan strategistrategi yang bertentangan dengan konsep pasar efisien. Teori Efficient MarketHypothesis menyatakan bahwa efek pada umumnya berada dalam kondisi ekuilibrium dimana saham tersebut dihargai secara wajar atau harganya mencerminkan keseluruhan informasi tentang saham yang tersedia bagi publik (Brigham, 2010). Hasil penelitian ini menunjukkan bahwa terdapat hubungan negatif dimana ketika EPS mengalami kenaikan, nilai perusahaan malah menurun (dan sebaliknya). Informasi laba yang ditunjukkan melalui EPS tidak mencerminkan harga saham yang merupakan dasar perhitungan nilai perusahaan.

Anomali yang terjadi kemungkinan karena ekspektasi investor terhadap laba perusahaan terlalu tinggi. Segera setelah informasi kenaikan laba tersebar luas di pasar, investor akan membandingkan angka laba di laporan keuangan dengan ekspektasi laba yang diharapkan (overreact terhadap pengumuman). Investor dengan ekspektasi tinggi akan memandang informasi kenaikan laba di laporan keuangan sebagai "bad news" (Linawati, 2004). Jika jumlah investor yang memandang "bad news" lebih banyak, maka harga saham akan mengalami penurunan. Perilaku investor yang sedemikian rupa dapat menyebabkan ketidakberaturan di pasar modal atau anomali pasar. Anomali pasar menciptakan hubungan yang tidak rasional antara informasi publik yang tersedia dengan harga saham, hal tersebut menjadikan sulit untuk dijelaskan.

\section{b. Pengaruh Pendapatan terhadap Nilai Perusahaan}

Hasil pengujian pendapatan menunjukkan hasil yang sesuai dengan dugaan peneliti. Setelah diuji secara parsial, variabel pendapatan mempunyai pengaruh yang signifikan terhadap nilai perusahaan, dapat dilihat dari nilai signifikan yang lebih kecil daripada taraf 0,044Nilai signifikansi Pendapatan yang lebih kecil dari signifikansi yang diharapkan $(0,05)$ dan dan t hitung sebesar 2,466> t tabel sebesar 2,04523 menunjukkan bahwa variabel Pendapatan berpengaruh positif dan signifikan terhadap nilai perusahaan sektor aneka industri yang terdaftar di Bursa Efek Indonesia periode 2015-2016, sehingga hipotesis kedua yang diajukan diterima. Oleh karena itu pendapatan dapat digunakan untuk memprediksi nilai perusahaan. Jadi, pendapatan ini memiliki pengaruh yang signifikan terhadap nilai perusahaan.

\section{c. Pengaruh Total Arus Kas terha- dap Nilai Perusahaan}

Hasil pengujian total arus kas menunjukkan hasil yang sesuai dengan dugaan peneliti. Setelah diuji secara parsial, variabel total arus kas mempunyai pengaruh yang signifikan terhadap nilai perusahaan, dapat dilihat dari nilai signifikan yang lebih kecil daripada taraf 0,044 Nilai signifikansi 182 dengan signifikansi 0,047 Nilai signifikansi Total Arus Kas yang lebih kecil dari signifikansi yang diharapkan $(0,05)$ dan $\mathrm{t}$ hitung sebesar 2,071> t tabel sebesar 
2,04523 menunjukkan bahwa variabel Total Arus Kas berpengaruh positif dan signifikan terhadap nilai perusahaan sektor aneka industri yang terdaftar di Bursa Efek Indonesia periode 20152016, sehingga hipotesis ketiga yang diajukan diterima. Oleh karena itu pendapatan dapat digunakan untuk memprediksi nilai perusahaan. Jadi, pendapatan ini memiliki pengaruh yang signifikan terhadap nilai perusahaan.

\section{Uji Simultan}

Hasil pengujian terhadap masingmasing variabel independen secara parsial menunjukkan hasil bahwa satu dari tiga variabel independen tersebut memiliki pengaruh yang signifikan terhadap nilai perusahaan. Meskipun salah satu dari variabel independen ada yang tidak memiliki pengaruh yang sgnifikan, hal ini tidak berarti bahwa variabel independen tersebut tidak memiliki pengaruh sama sekali terhadap nilai perusahaan. Variabel tersebut memiliki pengaruh terhadap nilai perusahaan namun dalam tingkat yang rendah. Hal ini mungkin disebabkan karena nilai perusahaan dipengaruhi oleh banyak faktor lainnya termasuk kondisi ekonomi dan keadaan sosial-politik negara.

Hasil pengujian ketiga variabel independen secara simultan terhadap variabel dependen menunjukkan hasil bahwa ketiga variabel independen secara simultan memiliki pengaruh yang signifikan terhadap nilai perusahaan. Terbukti dengan hasil dari signifikasi simultan bernilai 0,046. Tingkat signifikansi tersebut lebih kecil dari 0,05 dan F hitung sebesar 2,999> F tabel sebesar 2,93403, yang artinya secara keseluruhan ketiga variabel berpengaruh terhadap nilai perusahaan.

\section{F. KESIMPULAN}

Berdasarkan hasil analisis data mengenai pengaruh laba per saham, pendapatan,total Arus kas terhadap nilai perusahaan pada perusahaan aneka industri dan industri barang konsumsi sektor 4 dan 5 yang terdaftar di Bursa Efek Indonesia Periode 2015 - 2016, dapat disimpulkan bahwa:

1. Laba per saham berpengaruh negatif dan tidak berpengaruh signifikan terhadap nilaiperusahaan, hal ini dibuktikan dengan diperolehnya nilai koefisien regresi laba per saham sebesar -0,163 dengan signifikansi 0,140 . Sedangkan nilai signifikansi Laba per saham yang lebih besar dari signifikansi yang diharapkan $(0,05)$ dan $t$ hitung sebesar $-1,517<\mathrm{t}$ tabel sebesar 2,04523 menunjukkan bahwa variabel laba per saham berpengaruh negatif dan tidak signifikan terhadap nilai perusahaan aneka industri yang terdaftar di Bursa Efek Indonesia periode 2015-2016, sehingga hipotesis pertama yang diajukan ditolak.

2. Pendapatan berpengaruh positif dan berpengaruh secara signifikan terhadap nilai perusahaan, hal ini dibuktikan dengan diperolehnya nilai koefisien regresi Pendapatan sebesar 0,043 dengan signifikansi 0,044Nilai signifikansi Pendapatan yang lebih kecil dari signifikansi yang diharapkan $(0,05)$ dan dan t hitung sebesar $2,466>t$ tabel sebesar 2,04523 menunjukkan bahwa variabel pendapatan berpengaruh positif dan signifikan terhadap nilai perusahaan sektor aneka industri yang terdaftar di Bursa Efek Indonesia periode 20152016, sehingga hipotesis kedua yang diajukan diterima.

3. Total arus kas berpengaruh positif dan berpengaruh secara signifikan terhadap nilai perusahaan, hal ini dibuktikan dengan diperolehnya nilai koefisien regresi total arus kas 
sebesar 0,182 dengan signifikansi 0,047 Nilai signifikansi Total Arus Kas yang lebih kecil dari signifikansi yang diharapkan $(0,05)$ dan t hitung sebesar 2,071> t tabel sebesar 2,04523 menunjukkan bahwa variabel Total Arus Kas berpengaruh positif dan signifikan terhadap nilai perusahaan sektor aneka industri yang terdaftar di Bursa Efek Indonesia periode 2015-2016, sehingga hipotesis ketiga yang diajukan diterima.

4. Pengaruh laba per saham, pendapatan, total Arus kas secara simultan berpengaruh terhadap kebijakan hutang, hal ini dibuktikan dengan diperolehnya nilai signifikasi sebesar 0,046. Tingkat signifikansi tersebut lebih kecil dari 0,05 dan $\mathrm{F}$ hitung sebesar 2,999> F tabel sebesar 2,93403, yang artinya secara keseluruhan ketiga variabel berpengaruh terhadap nilai perusahaan, dapat disimpulkan bahwa Laba per saham, pendapatan, dan total arus kas secara stimultan berpengaruh terhadap nilai perusahaan, sehingga hipotesis yang ketiga diterima.

Penelitian ini memiliki beberapa keterbatasan diantaranya sebagai berikut:
1. Perusahaan yang dijadikan sampel penelitian hanya terbatas pada industri barang konsumsi dan aneka industri, sehingga kurang mewakili seluruh sektor industri yang ada di Bursa Efek Indonesia.

2. Penelitian ini menggunakan beberapa variabel yakni pengaruh laba per saham, pendapatan, total Arus kas sementara itu masih terdapat variabel-variabel penjelas lainnya seperti risiko bisnis, struktur aset, pertumbuhan perusahaan dan lain sebagainya

\section{SARAN}

1. Penelitian selanjutnya perlu untuk menambah atau mengganti beberapa variabel yang dimungkinkan berpengaruh terhadap nilai perusahaan seperti risiko bisnis, struktur aset, pertumbuhan perusahaan, dan lain sebagainya.

2. Para investor diharapkan dapat memperhatikan variabel Pendapatan dan total arus kas yang berpengaruh secara signifikan terhadap nilai perusahaan sebelum mengambil keputusan dalam melakukan investasi di pasar modal.

\section{DAFTAR PUSTAKA}

Harahap, Sofyan Syafri. (2006). Analisa Kritis Atas Laporan Keuangan, Grafindo Persana, Jakarta.

Husnan, Suad. (2003). Dasar-Dasar Teori Portofolio dan Analisis Sekuritas, AMP YKPN, Yogyakarta.

Indriantoro, Nur dan Bambang Supomo. (2002). Metodologi Penelitian Bisnis Untuk Akuntansi dan Manajemen, Edisi Pertama, BPFE, Yogyakarta.

Jones, Charles P. (2007). Investments: Tenth Edition. John Wiley \& Sons Pte Ltd

Sudarsono, J., et al. (2002). Pengantar Ekonomi Perusahaan. Jakarta: PT Prenhalindo. www.idx.co.id 